\title{
The Effect of Local Retributions, Remaining Budget Financing (SILPA) and Economic Growth on Capital Expenditure Allocation
}

\author{
Muti'ah Marsyaf Bambang Subiyanto
}

\begin{abstract}
This study analyses the effect of Regional Retribution, Excess Budget Financing (SILPA) and Economic Growth on Capital Expenditure Allocation in 33 Provinces in Indonesia, from 2014-2018. The sampling method is used purposive sampling. The data is used secondary data obtained from www.djpk.depkeu.go.id. The method of data analysis uses multiple linear regression analysis. From the it can be concluded that Regional Retribution has a positive and significant effect on Capital Expenditure Allocation, Excess Budget Financing (SILPA) has a positive and significant effect on Capital Expenditure Allocation, and Economic Growth has a negative effect on Capital Expenditure Allocation.
\end{abstract}

Keywords: Regional Retribution, Excess Budget Financing (SILPA), Economic Growth, Capital Expenditure Allocation.

DOI: $10.7176 / \mathrm{EJBM} / 12-25-10$

Publication date:September $30^{\text {th }} 2020$

\section{INTRODUCTION}

The regional autonomy is prevented the power at the central government, and to attract the people to participate in government, with the aim of improving public welfare, public services and regional competitiveness.

Capital expenditure is a budget expenditure in achieving fixed assets that can have a positive impact for more than one accounting period. Capital expenditures have an important influence on the economic growth of a region and have the ability to move the wheels of the regional economy, therefore the allocation of capital expenditures must be right on target and should be allocated for productive things. In the 2015-2019 National Medium-Term Development Plan, the Government set a capital expenditure proportion of around $30 \%-35$, however, this capital expenditure was not meet the target.

Regional government revenue comes from its own funding based on its capabilities, namely in the form of Regional Original Revenue (Regional Ratio). The greater the retribution receipt, the greater the funds allocated to finance activities related to the provision of public facilities and infrastructure which again have an impact on the welfare of the community. The former PT Smelting official, based on the Supreme Court's decision, was proven to have committed a criminal act of corruption. Regional treasury of the Gresik Regency Government related to terminal lease for its own interests.

SILPA is the difference in the realization of budget revenues and expenditures during one budget period. The Central Government hopes that development in each region grows high, the SILPA number 0 (zero) indicates that the budget absorption is 100 percent or the maximum, but the results of the 2018 APBD implementation evaluation, Aceh Province places the third highest SILPA position, ranks first and second in DKI Jakarta Province and West Java province.

Local governments as development mobilizers are very strategic in supporting the improvement of people's welfare and economic growth in their regions. Economic growth is an indicator to see the results of the development that has been carried out by the government. The Central Statistics Agency (BPS) noted that almost all regions in Indonesia have had positive economic growth. However, economic growth in Maluku \& Papua during 2019 contracted. The economy in Papua has continued to decline.

Heny (2017), Rachmi (2018) and Retno (2018) found that Regional Levies have a significant effect on Capital Expenditure Allocation. However, I Komang and I Ketut (2017) and Rifqi (2017) Regional Levies have no effect on Capital Expenditure Allocation. Irwanto, Kartika and Yuli (2018), Nurmala, Gustian and Sarwani (2018), Sandra and Sulistyo (2018) show that the Excess Budget Financing (SILPA) affects the Capital Expenditure Allocation. However, Agus, Hadioetomo and Agus H. (2019), Sri, Hasan and Mohammad (2019) Excess Budget Financing (SILPA) has no effect on Capital Expenditure Allocation. Bambang (2015), Pancawati and Rachmawati (2018) Eva, Mirna and Darwis (2019), found that economic growth affects the allocation of capital expenditures. However, Mundiroh (2019), Syukri and Hanaya (2019) Economic Growth has no effect on Capital Expenditure Allocation.

Because of the differences mentioned above, the authors are interested in correlation the effect of Regional Levies, Extra Budget Financing (SILPA) and Economic Growth on Capital Expenditure Allocation"

The first point is to analyze the effect of local levies on capital expenditure allocation. In an area with adequate economic conditions, a large enough regional levy will be obtained. The greater the receipt of user fees, the greater 
the funds allocated to finance activities related to the provision of public facilities and infrastructure which again have an impact on the welfare of the community. The second objective of this research is to analyze the effect of the remaining budget (SILPA) on the allocation of capital expenditures. If the SILPA is high, it shows how weak the financial performance of the Provincial Government is, if it is already in SILPA, so that the remaining funds can be reused for regional development. And the third objective of this study is to analyze the effect of economic growth on capital expenditure allocation. Economic growth is an indicator to see the development results that have been carried out by the government and is also useful in determining the direction of development in the future. Besides being able to provide new empirical evidence, this study can contribute to covering the gap between the results of previous studies. Therefore this research can be useful information for local governments in Indonesia to be able to manage regional finances more effectively.

This article has four parts. First, review the relevant literature Regional Retributions, Remaining Budget Financing (SILPA), Economic Growth and Capital Expenditure Allocation. Then the research methodology is presented and data analysis techniques are discussed. The next section discusses the research findings. The article concludes with a discussion of theoretical implications and local government, as well as suggestions for further research.

\section{THEORY}

\section{Legitimacy Theory}

Legitimacy theory states that an organization can only survive if the society in which it is located feels that the organization operates based on a value system that is commensurate with the value system owned by society. This theory examines the status of an individual or organization that is considered legitimate, an individual or organization is considered to exist if it is recognized by society.

\section{Capital Expenditures}

According to Ratmono and Sholihin (2015: 33) Capital expenditure is a budget expenditure for the acquisition of fixed assets and other assets that provide benefits for more than one accounting period. Capital expenditures are also aimed at replacing outdated government facilities and adding new fixed assets to meet the minimum service requirements (Hoesada, 2016: 238).

\section{Regional Retribution}

Regional levies are regional levies as payment for services or the granting of certain permits specifically provided and / or given by the regional government for the benefit of individuals or entities. In collecting levies also pay attention to the object and subject of levies such as local tax levies (Waluyo, 2013: 241)

\section{Remaining Budget Financing (SILPA)}

The remaining excess of budget financing (SILPA) is the excess of realized budget revenues and expenditures during one budget period which can later be used in the following year.

\section{Economic growth}

According to Sadono Sukirno (2015: 29) Economic growth is the development of economic activity that applies from time to time and causes real national income to grow.

\section{The Effect of Local Levies on the allocation of capital expenditures}

Regional levies in the PDRD Law are regional levies as payment for services or the granting of certain permits specifically provided and / or given by the Regional Government for the benefit of individuals or entities. In collecting levies also pay attention to the objects and subjects of levies such as local tax levies (Waluyo, 2013). The characteristic of a good levy is that it will increase every year. This shows that the region can manage its regional income well. The results of research by Heny (2017), Rachmi (2018) and Retno (2018) show that Regional Levies have a significant effect on Capital Expenditure Allocation.

H1: Regional Retribution affects Capital Expenditure Allocation

Effect of Remaining Budget Financing (SILPA) on Capital Expenditure Allocation

Remaining Budget Financing (SILPA) is the excess of realized budget revenues and expenditures during one budget period. The Central Government hopes that development in each region grows high, the SILPA figure in the APBA is 0 (zero) indicating that the absorption of the budget is 100 percent or the maximum. If the SILPA is high, it shows how weak the financial performance of the Provincial Government is, if it is already in SILPA, so that the remaining funds can be reused for regional development. The results of research by Irwanto, Kartika and Yuli (2018), Nurmala, Gustian and Sarwani (2018), Sandra and Sulistyo (2018) show that the Excess Budget Financing (SILPA) affects the Capital Expenditure Allocation.

H2: Excess Budget Financing (SILPA) affects the allocation of capital expenditures 
The Effect of Economic Growth on Capital Expenditure Allocation

Economic growth is a process of changing the economic conditions of an area on an ongoing basis towards a better condition during a certain period. Local governments as development mobilizers are very strategic in supporting the improvement of people's welfare and economic growth in their regions. Economic growth is an indicator to see the development results that have been carried out by the government and is also useful in determining the direction of development in the future. Research results by Bambang (2015), Pancawati and Rachmawati (2018) and Eva, Mirna and Darwis (2019), show that economic growth has a negative and significant effect on capital expenditure allocation.

H3: Economic growth affects the Allocation of Capital Expenditures

Based on the theoretical basis and previous research that has been described, it can be described schematically a framework of thought in this study as follows:

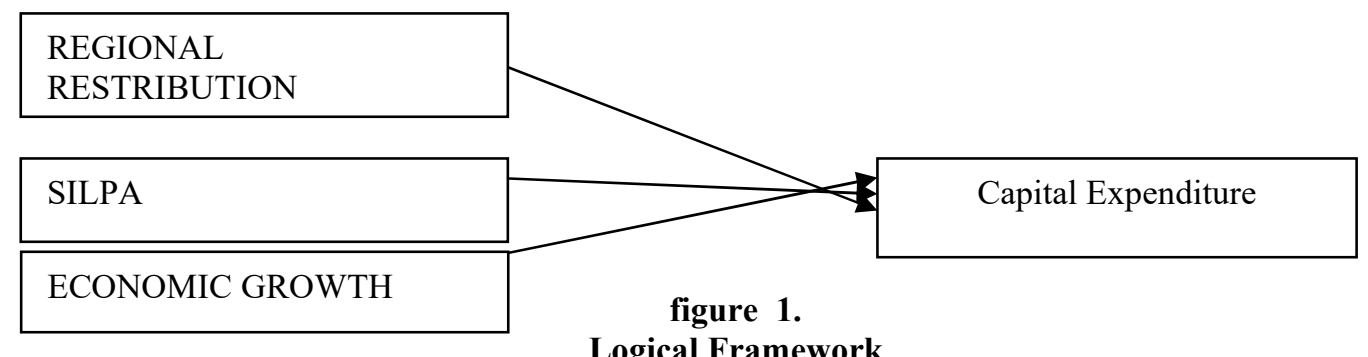

\section{METHOD}

This study uses secondary data, on regional finances from 33 provinces in Indonesia obtained from the website www.bps.go.id and www.djpk.depkeu.go.id from 2014-2018. The research data collection was done by using the documentation method.

Measurement

Regional Retribution, Remaining Budget Financing (SILPA), Economic Growth measurement scale used ratio scale, and Capital Expenditure Allocation measurement scale used ratio scale.

\section{Analysis Technique}

The data analysis technique used in this research is descriptive statistics and inferential statistics. Descriptive statistics are used to analyze data by describing or describing the collected data, and inferential statistics are statistical techniques used to analyze sample data. In this study, the inferential statistical data analysis used was multiple regression analysis, with the equation formula as follows:

$\mathrm{Y}=\mathrm{a}+\mathrm{b} 1 \mathrm{X} 1+\mathrm{b} 2 \mathrm{X} 2+\mathrm{b} 3 \mathrm{X} 3+\mathrm{e}$

\section{RESULTS AND DISCUSSION}

Descriptive Analysis

Descriptive statistical analysis is the analysis that aims to provide an overview or description of data in terms of the minimum value, maximum value, average value (mean), and standard deviation.

Table 1. Descriptive Analysis

\begin{tabular}{|l|r|r|r|r|r|}
\hline & $\mathrm{N}$ & \multicolumn{1}{|c|}{ Minimum } & Maximum & \multicolumn{1}{c|}{ Mean } & \multicolumn{1}{c|}{ Std. Deviation } \\
\hline RD & 165 & 0 & 689900 & 53682.70 & 103327.386 \\
SILPA & 165 & 0 & 13165646 & 830529.79 & 1738708.494 \\
PE & 165 & -4.56 & 21.76 & 5.4177 & 2.33518 \\
BM & 165 & 188754 & 16995195 & 1395509.92 & 1997551.319 \\
Valid N (listwise) & 165 & & & & \\
\hline
\end{tabular}

Sources secondary data 
Table 2. Regression analysis

\begin{tabular}{|c|c|c|c|c|}
\hline & B & Std. Error & $\mathbf{t}$ & Sig. \\
\hline (Constant) & 739.735 & 62.247 & 11.884 & 0.000 \\
\hline $\mathrm{RD}$ & 0.002 & 0.000 & 8.795 & 0.000 \\
\hline SILPA & 0.417 & 0.048 & 8.694 & 0.000 \\
\hline $\mathrm{PE}$ & -18.550 & 9.014 & -2.058 & 0.041 \\
\hline Dependent Var. & \multicolumn{4}{|c|}{ Capital expenditure } \\
\hline F calculation & \multicolumn{4}{|c|}{169.920} \\
\hline Sig F & \multicolumn{4}{|l|}{0.000} \\
\hline Durbin Watson & \multicolumn{4}{|l|}{1,847} \\
\hline R Square & \multicolumn{4}{|l|}{0.467} \\
\hline Adj. R Square & \multicolumn{4}{|l|}{0.456} \\
\hline
\end{tabular}

Sources secondary data

Coefficient of Determination (R2)

In table 2. it can be seen that the value of Adjusted R2 is 0.456 , this means that $45.6 \%$ of the variation in capital expenditure can be explained by the variation of the three independent variables (RD, SILPA, and PE). While the remaining $54.4 \%(100 \%-45.6 \%)$ are explained by reasons other than the model.

\section{Hypothesis test}

Simultaneous Significance Test (Test F)

In table 2 , the value of $F$ is 169,920 with a probability of 0.000 . Because the probability is much smaller than 0.01 , the regression model can be used to predict the Capital Expenditure Allocation. Or it can be said that RD, SILPA, and PE together have an effect on the Capital Expenditure Allocation, and the form of the linear regression equation is correct.

Test of Individual Significance (t test).

In table 2, of the three independent variables included in the regression model, all of them have a significant effect on the Capital Expenditure Allocation. This can be seen from the significance probability for RD of 0.000, SILPA of 0.000 , and PE of 0.041 . Thus it can be concluded that both RD, SILPA, and PE have a significant effect on alpha $1 \%$ on the Capital Expenditure Allocation.

\section{Regression Equations}

From the results of the calculation of the regression analysis as listed in Table 4.5, the regression equation formed is as follows:Capital expenditure allocation $=739,735+0.002 \mathrm{RD}+0.417$ SILPA $-18,550 \mathrm{PE}+\mathrm{e}$

\section{DISCUSSION}

The assumption in the first hypothesis is that local levies have an effect on the allocation of capital expenditures. This study found that the Regional Retribution has a positive and significant effect on the Capital Expenditure Allocation. This research strengthens the research of Retno (2018), Rubiyanto (2019) and Yeni, Anis and Tri (2019). It cannot be denied that Regional Levies are one of the determining factors in capital expenditure allocation. The APBD is prepared in accordance with the needs of government administration and the ability of the regions to generate revenue. For each preparation of the APBD, the allocation of capital expenditures must be adjusted to the needs of the region by taking into account the Regional Levies received. So that if the Regional Government wants to increase the allocation of capital expenditures for public services and public welfare, the Regional Government must explore the sources of Regional revenue as much as possible.

Meanwhile, the second hypothesis suspects that the remaining excess budget financing (SILPA) affects the Capital Expenditure Allocation. This study proves that the remaining excess budget financing (SILPA) has a positive and significant effect on capital expenditure allocation. This research strengthens the research of Nurmala, Gustian and Sarwani (2018), Sandra, Sulistyo and Rita (2018), and Noor Aini, Haryanto (2019), local governments have more information about their regions than the central government, thus enabling self-interest in budgeting. . The Remaining Budget Financing (SILPA) is the remaining budget as a result of revenue that is greater than expenditure, where the remaining budget can be used in the next period, to increase regional revenue in financing capital expenditures, so that the higher Remaining Budget Financing (SILPA), then capital expenditure will increase.

This study proves that economic growth has a negative and significant effect on capital expenditure allocation. This research is in line with the research of Bambang (2015), Pancawati and Rachmawati (2018) and Eva, Mirna and Darwanis (2019). Regional development aims to improve welfare and create social justice for all levels of society. For this reason, development requires the right approach, in order to generate growth accompanied by 
equity. Infrastructure plays an important role in improving the quality of life and human welfare. This can happen if the allocation of capital expenditures in a region is based on regional needs for facilities and infrastructure both for the smooth implementation of government duties and for public facilities.

\section{CONCLUSIONS}

The conclusions can be drawn as follows: Regional Levies have a positive and significant effect on Capital Expenditure Allocation, Remaining Budget Financing (SILPA) has a positive and significant effect on Capital Expenditure Allocation and Economic Growth has a negative and significant effect on Expenditure Allocation Capital.

Further research suggests the use of more complete data with a longer research period so that it is better able to see trends in the impact of public sector revenue sources on Regional Capital Expenditure Allocation. Subsequent research can also add to the investment opportunity variable, geographic factors from the City Government / Regency Government which also affect the Capital Expenditure Allocation.

\section{REFERENCES}

Afrisa Ayu Riska, Fitri Nur Ahmidati, Niezen Henry Lolowang, Rofiqoh Muthia

Anggraini. (2013). Pengaruh Pendapatan Asli Daerah dan Dana Perimbangan terhadap Pertumbuhan Ekonomi Daerah Tahun 2008-2012.

Andrey Yushkov. (2015). Fiscal Decentralization and Regional Economic Growth: Theory, Empirics and The Rusian Experience.

Baldric Siregar. (2015). Akuntansi Sektor Publik, UPP STIM YKPN.

C.O. Njoku, K.E. Ugwu, E.E. Chigbu. (2014). Government Publik Expenditures: Effect on Economic Growth (The Case of Nigeria, 1961-2013).

Erlina, Sakti, Rasdianto. (2015). Akuntansi Keuangan Daerah Berbasis Akrual. Jakarta: Salemba Empat.

Ghozali (2013) Aplikasi Analisis Multivariate Dengan Program SPSS. Semarang: BP Universitas Diponegoro.

Halim, Abdul dan Kusufi, Muhammad Syam. 2012. Akuntansi Keuangan Daerah. Jakarta: Salemba Empat.

Hamdani. (2016). Good Corporate Governance: Tinjauan Etika Dalam Praktik Bisnis. Jakarta: Mitra Wacana Media.

Hoesada, J. (2016). Akuntansi Pemerintahan (Bunga Rampai). Jakarta: Salemba Empat.

Irene Szarowska. (2015). impact of fiscal Decentralization on Economic Development in The European Union.

Jibir Adamu, Babayo Hajara. (2015). Government Expenditure and Economic Growth Nexus: Empirical Evidence from Nigeria.

Lukman Hakim. (2013). Pengaruh Belanja Modal terhadap Pertumbuhan Ekonomi (Studi Kasus Kabupaten dan Kota Pulau Jawa dan Bali).

Mardiasmo. (2018). Perpajakan (Edisi Terb). Yogyakarta.

Marwani, Darwanis, Syukriy Abdullah. (2013). Pengaruh Pendapatan Asli Daerah dan Dana Alokasi Umum terhadap belanja Modal serta dampaknya terhadap pertumbuhan ekonomi Daerah.

Mochamad Rizky Azzumar, dan Herniwati Retno handayani. (2012). Pengaruh Pendapatan Asli Daerah , Dana Perimbangan, Investasi swasta, Tenaga kerja terhadap pertumbuhan Ekonomi di Era desentralisasi fiskal tahun 2005-2009 (Studi Kasus Kabupaten/Kota Provinsi Jawa Tengah).

Ratna Mappanyuki. (2015). The Effect of Surplus Budget Financing, Special Allocation Fund, General Allocation Fund, Regional Revenue, and Characteristics of Local Goverment on Decision of Capital Expeniture (Survey in Local Goverment in Indonesia).

Ni Komang Ayuk Sumartini, I.G.W Murjana Yasa. (2013). Pengaruh PAD dan DAU Terhadap Perumbuhan Ekonomi Melalui Belanja Modal di Provinsi Bali.

Nurlis. (2016). The Factors Affecting of the Capital Expenditure Allocation Case: The Local Government of Indonesia.

Peraturan Pemerintah Republik Indonesia Nomor 33 Tahun 2014 tentang Pemerintahan Daerah.

Peraturan Pemerintah Republik Indonesia Nomor 55 Tahun 2005 Tentang Dana Perimbangan.

Peraturan Pemerintah Republik Indonesia Nomor 58 Tahun 2005 Tentang Pengelolaan Keuangan Daerah.

Punky Arhani. (2011). Pengaruh Pertumbuhan Ekonom, Pendapatan Asli Daerah, Dana Alokasi Umum, dan Dana Alokasi Khusus terhadap Pengalokasian Belanja Modal.

Rahardja,Prathama dan Manurung,Mandala. (2014). Teori Ekonomi Makro, Fakultas Ekonomi Universitas Indonesia.

Resiana Sukmawati, I Wayan Suwendra, Fridayana Yudiaatmaja. (2016). Pengaruh Pendapatan Asli Daerah dan Sisa Lebih Pembiayaan Anggaran terhadap Belanja Modal pada Pemerintah Dearah Kabupaten.

Santoso, Singgih. (2018). Menguasai Statistik dengan SPSS 25. Jakarta: PT Elex Media Komputindo.

Sukirno, sadono. (2012). Makroekonomi Teori Pengantar. Jakarta: PT Raja Grafindo Persada.

T.H. Tulus Tambunan. (2012). Perekonomian Indonesia, Ghalia Indonesia Anggota IKAPI. 
Todaro, Michael P dan Smith, Stephen C. 2015. Pembangunan Ekonomi. Jakarta: Penerbit Erlangga.

Tria Anindya Kirana. (2016). Analisis Pengarauh Pendapatan Asli Daerah, Belanja Modal, dan Sisa Lebih Pembiayaan Anggaran terhadap Pertumbuhan Ekonomi (studi kasus 38 Kota/ Kabupaten se-Jawa Timur Tahun 2009-2013).

Undang No. 33 Tahun 2004 Tentang Peribangan keuangan pemerintah Pusat dengan Daerah.

Zuwety Eka Putri. (2015). Anlisa pengruh pendapatan asli daerah, Dana Alokasi Umum dan Inflasi terhadap Pertumbuhan Ekonomi di Kabupaten/Kota Provinsi Jawa tengah tahun 2011-2014.

Others:

Diunduh dari website Badan Pemeriksa Keuangan

Diunduh dari website Badan Pusat Statistik

Diunduh dari website Kementerian Keuangan

Diunduh dari website Komite Pemantauan Pelaksanaan Otonomi Daerah

https://aceh.tribunnews.com/2019/06/26/silpa-rp-16-t-siapa-yang-lalai

https://finance.detik.com/berita-ekonomi-bisnis/d-4886766/5-kali-berturut-ekonomi-papua-minus-inipenyebabnya 